\title{
Animal model for progressive resistance exercise: a detailed description of model and its implications for basic research in exercise
}

\author{
Ricardo Cardoso Cassilhas ${ }^{1,2}$ \\ Ismair Teodoro Reis ${ }^{3}$ \\ Daniel Venâncio ${ }^{2}$ \\ Jansen Fernandes ${ }^{2}$ \\ Sérgio Tufik ${ }^{2}$ \\ Marco Túlio de Mello ${ }^{1,2}$ \\ ${ }^{1}$ Centro de Estudos em Psicobiologia e Exercício, Universidade Federal de São Paulo, SP, Brasil \\ ${ }^{2}$ Departamento de Psicobiolgia, Universidade Federal de São Paulo (UNIFESP), SP, Brasil \\ ${ }^{3}$ Laboratório de Bioquímica e Biologia Molecular, Instituto de Genética e Bioquímica, Universidade Federal de \\ Uberlândia, Uberlândia, MG, Brasil
}

\begin{abstract}
The Several animal models have been proposed for resistance training. In addition, the results of these studies have been highly variable. Some of the studies have used negative reinforcement, electric shock or food deprivation to motivate the learning of the task. Features such as conditioning through electric shock may undermine the significance of the results or even prevent the model from being successfully executed. Due to these reasons, in this study we propose to use an adaptation of the vertical ladder climbing model for progressive resistance training in rats, albeit with a unique feature to ensure the homogeneity of the study groups: a period of adaptation to the apparatus without any negative reinforcement followed by a subsequent pairing of animals based on their ability to learn. The animals were distributed in the experimental group who were subjected to 8 weeks of a progressive resistance exercise protocol and the control group. After 8wks, the gastrocnemius, soleus, flexor digitorum longus (FDL), and plantaris muscles were removed and the cross-sectional area morphometry was obtened. The animals from experimental group showed hypertrophy $[F(4,15)=17,404, P \leq 0.001]$ for gastrocnemius $[60 \%$ of hipertrophy; Control $(2628,64 \pm 348,50)$ versus Experimental $(4207,77 \pm 1256,52)$; ES=1.96; Power=0,86]; FDL [35\% of hipertrophy; Control $(2753,80 \pm 359,54)$ versus Experimental $(3711,84 \pm$ 279,45); $E S=2.99$; Power $=0.99]$ and plantaris $[38 \%$ of hipertrophy; Control $(2730,44 \pm 320,56)$ versus Experimental $(3767,30 \pm 625,80)$; $E S=2.19$; Power $=0.92$ ], without modifications for soleus. All animals successfully completed the 8-week progressive resistance training program without any injuries, abandonment or death. Negative reinforcements such as electric shock were not required at any time in the experiment. In conclusion, we showed an adaptation of the previus model for progressive resistance training in rats. A period of adaptation to the apparatus without any negative reinforcement followed by a subsequent pairing of animals based on their ability to learn may be a alternative strategy for the original protocol. We also observed hypertrophy (gastrocnemius, FDL, and plantaris) showed the vality of this procolos for resistance exercise issues. The results of this study may be useful in basic/ applied neuroscience research and resistance exercise.
\end{abstract}

Keywords: Strength training. Hypertrophy. Animals. Exercise. Vertical ladder climbing model.

\section{Modelo animal de exercício resistido progressivo: descrição detalhada do modelo e a sua implicação à pesquisa básica com exercício}

Resumo: Alguns modelos animais de treinamento resistido vem sendo proprostos ao longo do tempo, com resultados variáveis e por vezes conflitantes. Contudo, todos eles utilizam reforço negativo ao ensinar os animais o aprendizado da tarefa, por exemplo, choque elétrico ou privação alimentar e tais condicionamentos podem interferir de algma forma na variável estudada. Por estas razões, este estudo propões uma adaptação de um modelo de treinamento resistido de subida em escada vertical já existente, mas com um período de familiarização ao equipamento, sem choque elétrico, seguido pela distribuição de acordo com o desempenho do aprendizado de subida em escada. Os animais foram distribuídos em: grupo experimental (submetido a oito semanas de treinamento resistido) e grupo controle. Após a intervenção, os músculos gastrocnemius, soleus, flexor digitorum longus (FDL), and plantaris foram removidos e a moformetria das fibras muculares foi realizada. Os animais do grupo experimental mostraram hipertrofia $[F(4,15)=17,404, P \leq 0.001]$ nos músculos: gastrocnemius $[60 \%$ de hipertrofia; Control $(2628,64 \pm 348,50)$ versus Experimental $(4207,77 \pm 1256,52)$; $\mathrm{ES}=1.96$; Power $=0,86]$; FDL $[35 \%$ de hipertrofia; Control $(2753,80 \pm 359,54)$ versus Experimental $(3711,84 \pm$ 279,45); ES=2.99; Power $=0.99]$ e plantaris [38\% de hipertrofia; Control $(2730,44 \pm 320,56)$ versus Experimental $(3767,30 \pm 625,80)$; ES=2.19; Power=0.92], sem alterações no soleus. Ainda, todos os animais completaram o protocolo sem qualquer lesão, abandono ou morte. Reforço negativo como choque elétrico ou de outra natureza não foi realizado por todo o experimento. Concluindo, foi mostrado uma adaptação de modelo de treinamento resistido progressivo em ratos. Um período de adaptação ao aparato sem qualquer reforço negativo somado a um período de adaptação baseado na distribuição de acordo com o desempenho do aprendizado de subida em escada, pode ser uma estratégia ao protocolo original. Foi mostrado também hipetrofia (gastrocnemius, FDL, and plantaris) o que mostra a validade deste protocolo para o treinamento resistido. Os resustados do presente podem ser utilizados em pesquisa sobre neurociências básica/ aplicada e exercício resistido.

Palavras-chave: Treinamento resistido. Hipertrofia. Animais. Exercício. Modelo de escada vertical. 


\section{Introduction}

Several animal models have been proposed for resistance training and have aimed to mimic the physiological effects exhibited by humans in response to resistance exercise using rodents that are subjected to the same type of exercise ( $\underline{\mathrm{HO}}$, ROY, TWEEDLE, HEUSNER, VAN HUSS, CARROW, 1980; KLITGAARD, 1988; TAMAKI, UCHIYAMA, NAKANO, 1992; YARASHESKI, LEMON, GILLOTEAUX, 1990). However, the results of these studies have been highly variable. Some features that may account for the diversity must be mentioned. First, the designs of the apparatus used in the studies have been diverse, with different training protocols. Second, the relationship between volume and intensity has not always been taken into consideration to cause the expected adaptive effects. Finally, some of the studies have used negative reinforcement, electric shock or food deprivation to motivate the learning of the task (HO, ROY, TWEEDLE, HEUSNER, VAN HUSS, CARROW, 1980; KLITGAARD, 1988; TAMAKI, UCHIYAMA, NAKANO, 1992; YARASHESKI, LEMON, GILLOTEAUX, 1990).

Depending on the objective of the experiment, features such as conditioning through electric shock can undermine the significance of the results or even prevent the model from being successfully executed. Electric shock is a highly stressful stimulus that can supress or even exacerbate certain types of behavior in the animal. Therefore, the use of a resistance training method and learning process without any negative reinforcement may be of significant interest to the research community. Such a method would eliminate the pain stimulus in the animal and thereby avoid potential masking effects in the results.

Developing an animal model of resistance training that closely resembles training in humans is of utmost importance. There is a growing need to understand the mechanisms through which resistance training influences physiological traits; thus allowing improvements in the training. This type of training is widely recommended for adults and elderly, not only for the improvement of bone mineral mass, strength and muscle mass, but also for the management and prevention of several chronic degenerative diseases (HASKELL, LEE, PATE, POWELL, BLAIR, FRANKLIN, MACERA, HEATH, THOMPSON, BAUMAN, 2007). Furthermore, resistance training has also been linked with improvements in cognitive function (PERRIG-CHIELLO, PERRIG, EHRSAM, STAEHELIN, KRINGS, 1998; ÖZKAYA, AYDÝN, TORAMAN, KÝZÝLAY, CETINKAYA, 2005; CASSILHAS, VIANA, GRASSMANN, SANTOS, SANTOS, TUFIK, DE MELLO, 2007), anxiety and mood disorders (SINGH, CLEMENTS, SINGH, 2001; SINGH, CLEMENTS, FIATARONE, 1997; SINGH, STAVRINOS, SCARBEK, GALAMBOS, LIBER, FIATARONE SINGH, 2005; CASSILHAS, ANTUNES, TUFIK, DE MELLO, 2010).

There is a need to formulate an animal model (in rats) with the characteristics of progressive resistance training that are recommended for humans. Moreover, the model must also account for the welfare of the animal and must not use negative reinforcements such as electric shock to motivate the learning of the task. Stress induced by the negative reinforcement can mask the real effect of physical exercise by modulating several neurobiological pathways and impairing the overallcognitive process (LUPIEN, MAHEU, TU, FIOCCO, SCHRAMEK, 2007; KIM, HALLER, 2007; LI, WANG, WANG, DONG, HOU, TANG, 2008).

Due to these reasons, in this study we propose to use an adaptation of the vertical ladder climbing model proposed by (HORNBERGER, FARRAR, 2004) for progressive resistance training in rats. The model has also been described in other studies (DUNCAN, WILLIAMS, LYNCH, 1998; YARASHESKI, LEMON, GILLOTEAUX, 1990), albeit with a unique feature to ensure the homogeneity of the study groups: a period of adaptation to the apparatus without any negative reinforcement followed by a subsequent pairing of animals based on their ability to learn.

\section{Animals}

\section{Methods}

In this study, which received authorization (no. 778/07) from the Research Ethics Committee at the Universidade Federal de São Paulo - Hospital São Paulo, 20 Wistar EPM-1 adult rats (90 days old at the start of the experiment) were distributed into sets of five animals per cage. The animals were provided by the Center for the Development of Experimental Models for Medicine and Biology (Centro de Desenvolvimento de Modelos Experimentais para a Medicina e Biologia CEDEME) at the Universidade Federal de São Paulo (UNIFESP). 
The study was conducted in a temperature and light-controlled environment at $23 \pm 2^{\circ} \mathrm{C}$, with a light:dark cycle of 12:12 hrs (the lights were turned on at $7 \mathrm{am}$ ). The animals were given water and rat feed ad libitum in a hygiene-controlled environment.

\section{Experimental Procedure}

The animals were divided into two groups, control $(n=10)$ and experimental $(n=10)$, based on "ladder climbing performance" pairing, which will be described later.

\section{Control Group}

The control animals remained in their cages for the entire experimental period and were handled at least once daily to reduce the stress associated with experimental testing. This minimum daily handling process was used to weigh the animals throughout the intervention.

\section{Experimental Group}

The animals in the experimental group were subjected to 8 weeks of a progressive resistance exercise protocol with a frequency of fives times per week (Monday to Friday).

\section{Protocol and training apparatus}

The apparatus used for the training of the animals was adapted from a previous study (HORNBERGER, FARRAR, 2004). This apparatus has been successfully used to mimic the positive physiological adaptations of resistance training observed in humans using rat models (DUNCAN, WILLIAMS, LYNCH, 1998; YARASHESKI, LEMON, GILLOTEAUX, 1990). It consists of a $110-\mathrm{cm}$ high and $18-\mathrm{cm}$ wide ladder angled at $80^{\circ}$ and with a spacing of $2 \mathrm{~cm}$ between the steps. At the top of the ladder is a $20 \times 20 \times 20$ $\mathrm{cm}$ chamber that serves as a shelter during the period of rest between a series of climbs. At the base of the ladder, we fixed a structure that kept the bottom of the ladder away from the floor, with no contact between the floor and the tail of the animal or the overload system.

The training protocol was started three days after the adaptation period and consisted of 8 series of climbs on the ladder with progressive overload. Each series contained an average of 8 to 12 climbing movements (repetitions). In the first two repetitions, the overload was set at $50 \%$ of the total body mass of the animal. Then, the overload was increased to the following percentage of the body mass depending on the series: $75 \%$ for the third and fourth series, $90 \%$ for the fifth and sixth series, and $100 \%$ for the seventh and eighth series. In each series interval, the animal was made to rest for 60 seconds in the shelter at the top of the ladder.

The overload was fixed using the following two items: $13.5 \mathrm{~cm}$ of stainless steel cable joined together to form a circle and one Coastlock Snap Swivel to secure each of the cylinders used in the exercise. The Coastlock Snap Swivel was fixed to the tail of the animal (in the proximal portion) using Scotch 23 Rubber Tape (Scotch 3M) and was then attached to each cylinder, depending on the number of repetitions in the training session. The Scotch 23 Rubber Tape was adequately strong and did not leave any sticky residue or hurt the tail of the animal.

\section{Familiarization - ladder climbing performance}

Familiarization of the animals to the apparatus was performed using the same criterion that was used to distribute the animals into the two groups, i.e., pairing based on ladder climbing performance. Familiarization was conducted for three days and consisted of three attempts. Before the first attempt, the animal was kept in the chamber at the top of the ladder for 60 seconds to allow it to realize that the environment posed no threat. On the first attempt, the animal was placed on the proximal portion of the ladder at an approximate distance of $35 \mathrm{~cm}$ from the door of the chamber. This attempt was considered an easy attempt because the distance to the "safe place" was short. On the second attempt, the animal was positioned on the middle of the ladder at a distance of approximately $55 \mathrm{~cm}$ from the door of the chamber. This attempt was considered a medium difficulty attempt. On the third attempt, the animal was placed at the bottom of the ladder at a distance of approximately $110 \mathrm{~cm}$ from the door of the chamber. This attempt was considered the principal attempt. On the third attempt of each day, the ladder climbing time (in seconds) was measured. The climbing time was observed over the three days and used to divide the animals into groups as shown below. A reduction in climbing time signified a learning pattern. Based on the measured climbing time, each animal was distributed into the groups. A Student's t-test was performed to verify if all animals were homogenously distributed. Table 1 below shows the performance of the animals on the third climbing attempt on each of the three days of familiarization. 
Table 1. Ladder climbing performance during familiarization of groups.

\begin{tabular}{|c|c|c|c|c|c|c|}
\hline & & Days & familiarization $\left(3^{\text {rd }}\right.$ at & pt of $\epsilon$ & day) & \\
\hline & $\begin{array}{l}\text { Day } 1 \\
\text { (Time to climb the } \\
\text { ladder in seconds) }\end{array}$ & $p$ & $\begin{array}{c}\text { Day } 2 \\
\text { (Time to climb the } \\
\text { ladder in seconds) }\end{array}$ & $p$ & $\begin{array}{c}\text { Day } 3 \\
\text { (Time to climb the } \\
\text { ladder in seconds) }\end{array}$ & $p$ \\
\hline Control & $36.40 \pm 19.75$ & & $24.00 \pm 18.48$ & & $19.93 \pm 10.21$ & \\
\hline Experimental & $38.81 \pm 20.20$ & 0.79 & $15.79 \pm 5.08$ & 0.10 & $15.36 \pm 7.25$ & 0.26 \\
\hline
\end{tabular}

The values are presented as the mean \pm SD of time (seconds) to climb the ladder on the third trial of each day. The Student's t-test was adopted.

\section{Tissues Collection and Processing}

Twenty four hours after the final training session, the rats were euthanized by decapitation and the gastrocnemius, soleus, flexor digitorum longus (FDL), and plantaris muscles of the rigth leg were removed, coated in embedding medium (Tissue-Tek OCT, Miles, Naperville, IL, USA) and immersed in liquid nitrogen-cooled isopentane. All tissues were stored at $-80^{\circ} \mathrm{C}$ until use.

\section{Measurement of fibers cross-sectional area}

Transverse sections ( $8 \mu \mathrm{m}$ thick) were cut from the mid-bellies in a cryostat at $-20^{\circ} \mathrm{C}$, melted onto poly-L-Lysine coated microscopic slides (Superfrost, Fisher Scientific) and stained with Meyer's hematoxylin-eosin (H\&E). Digital images of $\mathrm{H} \& \mathrm{E}$ stained sections were taken with Olympus brightfield microscope BX50, camera DP71 (Melville, NY) with a $40 \mathrm{X}$ objective. The blinded analysis of cross-sectional area of 100 fibers per a muscle sample was performed using the software Axio Vision 4.6 (Carl Zeiss Microlmaging $\mathrm{GmbH}$ ).

\section{Statistical Analyses}

The software Statistica was used for all statistical analysis. The Shapiro-Wilk's W test was used to verify data normality. For parametric variables, we used a one-way ANOVA (FCSA of gastrocnemius, soleus, FDL, and plantaris muscles) or ANOVA for repeated measurements (weight of animals) followed by Tukey's post-hoc test. The significance level was set at 5\% $(95 \% \mathrm{Cl})$, and the data were presented as mean +/- standard deviation (SD). The statistical power (power analysis) and the effect size (ES) was defined as small, 0.2 to 0.49 ; medium, 0.5 to 0.79 ; and large, 0.8 to 2.0 (COHEN, 1988).

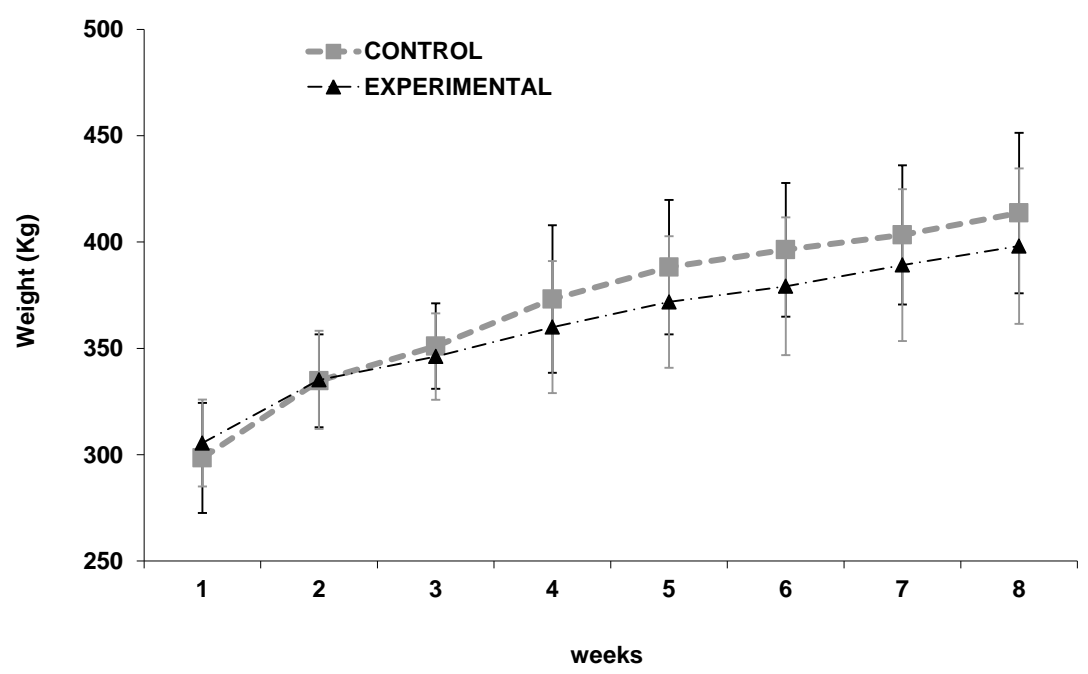

Weight of rats in control group $(n=10)$ and experimental group $(n=10)$ weekly during the intervention. Two-way ANOVA followed by Tukey's post-hoc test was adopted. The values are presented as the mean \pm SD.

Figure 1. Weights of animals over the 8-week experimental period. 


\section{Results}

All animals successfully completed the 8-week progressive resistance training program without any injuries, abandonment or death. Negative reinforcements such as electric shock were not required at any time in the experiment.
Figure 1 shows the body weight of the animals during the 8-week training period. No significant or unexpected differences in weight gain were observed between the control and experimental groups in the 8-week period.

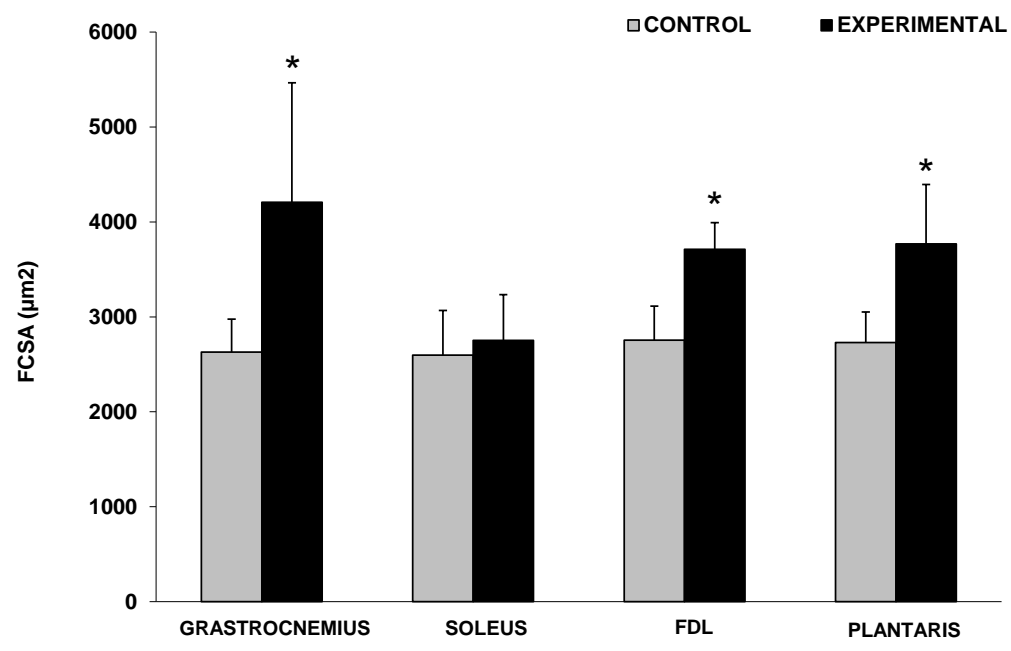

Fibers cross-sectional area (FCSA) in gastrocnemius, soleus, FDL and plantaris of rats in control group $(n=10)$ and experimental group $(n=10)$ after 8 wks of intervention. The one-way ANOVA followed by the Tukey's post hoc test was adopted. The values are presented as the mean $\pm \mathrm{SD} .{ }^{*} P<0.001$ compared with the control group.

Figure 2. Average fiber cross-sectional area of muscles.

Figure 2 shows the FCSA of the muscles. We found that after 8 weeks, the FCSA was larger in the experimental group compared to the control group $[F(4,15)=17,404, \quad P \leq 0.001]$ for gastrocnemius $[60 \%$ of hipertrophy; Control $(2628,64 \pm 348,50)$ versus Experimental $(4207,77$ \pm 1256,52); ES=1.96; Power=0,86]; FDL [35\% of hipertrophy; Control $(2753,80 \pm 359,54)$ versus Experimental $\quad(3711,84 \pm 279,45) ; \quad E S=2.99$; Power $=0.99]$ and plantaris [38\% of hipertrophy; Control $(2730,44 \pm 320,56)$ versus Experimental $(3767,30 \pm 625,80) ; \quad E S=2.19$; Power=0.92]. However, no significant difference was observed for soleus.

\section{Discussion}

Due to concerns regarding weight gain in the animals throughout the experiment, all animals were weighed daily. We did not find any significant or unexpected change in weight in the experimental group. This indicates that the animals in the experimental group adapted to the stress of physical exercise and remained healthy, similar to the control group, and they continued to gain weight as they aged.
Despite the lack of difference in body weight between the two groups, the experimental group showed a morphological change in the muscles, which are responsibles for the kinetic motion of the animals on the apparatus. After the histological assay and the quantification of the increase in gastrocnemius, FDL, and plantaris fibers, we observed that the experimental group suffered $60 \%, 35 \%$ and $38 \%$ of hypertrophy, respectively compared to the control group. This hypertrophy in the muscles analysed is a clear indicator that the apparatus and the training were able to mimic the major adaptive responses to resistance training. In a previous study which used a similar protocol, reported a hypertrophy of $23 \%$ (HORNBERGER, FARRAR, 2004). In similar study it was observed a hypertrophy of $17.5 \%$ (LEE, FARRAR , 2003). Other researchers have also reported different levels of hypertrophy in other muscles $(\underline{\mathrm{HO}}, \mathrm{ROY}$, TWEEDLE, HEUSNER, VAN HUSS, CARROW, 1980; KLITGAARD, 1988; TAMAKI, UCHIYAMA, NAKANO, 1992; YARASHESKI, LEMON, GILLOTEAUX, 1990; GORDON, KOWALSKI, FRITTS, 1967).

The muscle hypertrophy observed in our study is a reflection of the increased muscle workload mediated by the model. Several cellular pathways 
are candidates for the development of hypertrophy, of which the IGF-1 pathway should be emphasized. The increase in IGF-1 expression that occurs with strength training activates PIK3, which phosphorylates AKT. This pathway culminates with the phosphorylation of mTOR and activation of $\mathrm{s} 6 \mathrm{kp} 70$, which increases protein synthesis, and NFK-B which increases survival (PHILIPPOU, HALAPAS, MARIDAKI, KOUTSILIERIS, 2007).

These results, along with the success of the process in facilitating task-learning without the use of electric shock or other negative reinforcement stimuli, make this model a very interesting alternative, especially when the experimental design must investigate the relationship between resistance training and other variables that may be affected by aversive stimuli.

In conclusion, we showed an adaptation of the previus model for progressive resistance training in rats. A period of adaptation to the apparatus without any negative reinforcement followed by a subsequent pairing of animals based on their ability to learn may be a alternative strategy for the original protocol. We also observed hypertrophy (gastrocnemius, FDL, and plantaris) showed the vality of this procolos for resistance exercise issues. The results of this study may be useful in basic/ applied neuroscience research and resistance exercise.

\section{Acknowledgments}

This study was supported by the São Paulo Research Foundation (FAPESP) (grant number 2008/03083-6), Research Incentive Fund Association (AFIP), Psychobiology and Exercise Research Center (CEPE), Multidisciplinary Center for the Study of Drowsiness and Accidents (CEMSA), Research Innovation and Dissemination Centers-SLEEP (CEPID-Sleep), and the National Council for Scientific and Technological Development (CNPq).

\section{References}

CASSILHAS, R. C.; ANTUNES, H. K.; TUFIK, S.; DE MELLO, M. T. Mood, anxiety, and serum IGF1 in elderly men given 24 weeks of high resistance exercise. Perceptual and Motor Skills, Missoula, v. 110, n.1, p. 265-276, 2010.

CASSILHAS, R. C.; VIANA, V. A.; GRASSMANN, V.; SANTOS, R. T.; SANTOS, R. F.; TUFIK, S.; MELLO, M. T. The impact of resistance exercise on the cognitive function of the elderly. Medicine and Science in Sports and Exercise, Natick, v. 39, n.8, p.1401-1407, 2007.

COHEN J. Statistical power analysis for the behavioral sciences. Hillsdale, NJ: Lawrence Earlbaum, 1988.

DUNCAN, N. D.; WILLIAMS, D. A.; LYNCH, G. S. Adaptations in rat skeletal muscle following longterm resistance exercise training. European Journal of Applied Physiology and Occupational Physiology, New York, v. 77, n.4, p. $372-378,1998$.

GORDON, E. E.; KOWALSKI, K.; FRITTS, M. Changes in rat muscle fiber with forceful exercises. Archives of Physical Medicine and Rehabilitation, Philadelphia, v. 48, p. 577-582, 1967.

HASKELL, W. L.; LEE, I. M.; PATE, R. R.; POWELL, K. E.; BLAIR, S. N.; FRANKLIN, B. A.; MACERA, C. A.; HEATH, G. W.; THOMPSON, P. D.; BAUMAN, A. Physical activity and public health: updated recommendation for adults from the American College of Sports Medicine and the American Heart Association. Medicine and Science in Sports and Exercise, Natick, v. 39, p. 1423-1434, 2007.

HO, K. W.; ROY, R. R.; TWEEDLE, C. D.; HEUSNER, W. W.; VAN HUSS, W. D.; CARROW, R. E. Skeletal muscle fiber splitting with weight-lifting exercise in rats. American Journal of Anatomy, Malden, v. 157, p. 433-440, 1980.

HORNBERGER, T. A., JR.; FARRAR, R. P. Physiological hypertrophy of the FHL muscle following 8 weeks of progressive resistance exercise in the rat. Canadian Journal of Applied Physiology, Champaign, v. 29, p. 16-31, 2004.

KIM, J. J.; HALLER, J. Glucocorticoid hyper- and hypofunction: stress effects on cognition and aggression. Annals of the New York Academy of Science, New York, v. 1113, p. 291-303, 2007.

KLITGAARD, $\mathrm{H}$. A model for quantitative strength training of hindlimb muscles of the rat. Journal of Applied Physiology, Bethesda, v. 64, p. 17401745, 1988.

LEE, S.; FARRAR, R. P. Resistance training induces muscle-specific changes in muscle mass and function in rat. Journal of Exercise Physiology, Bethesda, v. 6, p. 80-87, 2003.

LI, S.; WANG, C.; WANG, W.; DONG, H.; HOU, P.; TANG, Y. Chronic mild stress impairs cognition in mice: from brain homeostasis to behavior. Life Science, Cheltenham, v. 82, p. 934-942, 2008. 
LUPIEN, S. J.; MAHEU, F.; TU, M.; FIOCCO, A.; SCHRAMEK, T. E. The effects of stress and stress hormones on human cognition: Implications for the field of brain and cognition. Brain and Cognition, Orlando, v. 65, p. 209-237, 2007.

ÖZKAYA, G. Y.; AYDÝN, H.; TORAMAN, F. N.; KÝZÝLAY, F.; CETINKAYA, V. Effect of strength and endurance training on cognition in older people. Journal of Sports Science and Medicine, Bursa, v. 4, p. 300-313, 2005.

PERRIG-CHIELLO, P.; PERRIG, W. J.; EHRSAM, R.; STAEHELIN, H. B.; KRINGS, F. The effects of resistance training on well-being and memory in elderly volunteers. Age and Ageing, Oxford, v. 27, p. 469-475, 1998.

PHILIPPOU, A.; HALAPAS, A.; MARIDAKI, M.; KOUTSILIERIS, M. Type I insulin-like growth factor receptor signaling in skeletal muscle regeneration and hypertrophy. Journal of Musculoskeletal and Neuronal Interactions, Kifissia, v. 7, p. 208-218, 2007.

SINGH, N. A.; CLEMENTS, K. M.; FIATARONE, M. A. A randomized controlled trial of progressive resistance training in depressed elders. The Journals of Gerontology, Series A, Biological Sciences and Medical Sciences, Washington, v. 52, p. M27-M35, 1997.

SINGH, N. A.; CLEMENTS, K. M.; SINGH, M. A. The efficacy of exercise as a long-term antidepressant in elderly subjects: a randomized, controlled trial. The Journals of Gerontology, Series A, Biological Sciences and Medical Sciences, Washington, v. 56, p. M497-M504, 2001.

SINGH, N. A.; STAVRINOS, T. M.; SCARBEK, Y.; GALAMBOS, G.; LIBER, C.; FIATARONE SINGH, $M$. A. A randomized controlled trial of high versus low intensity weight training versus general practitioner care for clinical depression in older adults. The Journals of Gerontology, Series A, Biological Sciences and Medical Sciences, Washington,v. 60, p. 768-776, 2005.

TAMAKI, T.; UCHIYAMA, S.; NAKANO, S. A weight-lifting exercise model for inducing hypertrophy in the hindlimb muscles of rats. Medicine and Science in Sports and Exercise, Natick, v. 24, p. 881-886, 1992.

YARASHESKI, K. E.; LEMON, P. W.; GILLOTEAUX, J. Effect of heavy-resistance exercise training on muscle fiber composition in young rats. Journal of Applied Physiology, Bethesda, v. 69, p. 434-437, 1990.
Agradecimentos: Estudo realizado com apoio da Associação Fundo de Incentivo à Pesquisa (AFIP); FAPESP (projeto №. 2008/03083-6) e $\mathrm{CNPq}$

\author{
Endereço: \\ Marco Túlio de Mello \\ Rua Francisco de Castro, 93 \\ São Paulo SP Brasil \\ 04020-050 \\ Tel./Fax: +55 11 5572-0177 and +55 11 5083- \\ 6900 \\ e-mail: tmello@demello.net.br
}

Recebido em: 25 de fevereiroo de 2012.

Aceito em:22 de março de 2013.

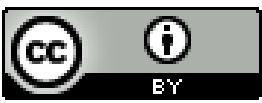

Motriz. Revista de Educação Física. UNESP, Rio Claro, SP, Brasil - elSSN: 1980-6574 - está licenciada sob Creative Commons - Atribuicão 3.0 